\title{
THE MILITARY THOUGHT OF KING ASHUR NASIR PAL II IN THE PHOENICIAN CITIES (883-859 BC)
}

\author{
Lecture: MuntahaNeamah Oudah \\ Department of History, Faculty of Education Ibn Rushd for Humanity, University of Baghdad
}

DOI: $10.37648 /$ ijrssh.v10i02.003

Received:05 ${ }^{\text {th }}$ December, 2019; Accepted:02 ${ }^{\text {nd }}$ January, 2020; Published: $29^{\text {th }}$ January, 2020

\begin{abstract}
This research for the military thought of one of the kings of the Assyrian state, known for its cruelty and hardness before the adversaries, is considered the greatest Assyrian figure (King Ashur Nasser Pal II) and applied the doctrine of military ideology (strike before being beaten), who inherited from his predecessors a seasoned army and combat doctrine proved and adopted His successors. The reign of King Ashur Pal II witnessed several important developments on the military, political and cultural levels. The method of killing and torture applied to some cities or villages, which was difficult for the Assyrian army to open. The most important military campaign of his reign was the occupation of the Phoenician cities, which enjoyed many of the most important economic advantages, hence the research shows the impression that this king had in the Phoenician cities.

Key words: Ashur Nasir pal II, Phoenician cities, Mesopotamia
\end{abstract}

\section{INTRODUCTION}

Our research was chosen under the title (The Military Thought of King Ashur Nasir Pal II in the Phoenician cities) and it is a civilized historical study that highlights an important aspect of the ambitions of the rulers and kings of Mesopotamia in the Phoenician cities. It is one of the most important periods of ancient history, and the research aims to give a brief picture of those ambitions. The cities of the Phoenician coast were of great importance to the rulers and kings of Mesopotamia, as these rulers and kings sought from ancient times to reach the Cedar Forest and to the Mediterranean and exploit Those resources before and after the Assyrian Empire and even before the rise of the Phoenician cities. In fact, the fact that Syria is generally located in an important region between two civilizations and political and economic powers in
Mesopotamia and Egypt made it the executor of their economic and military ambitions. Among the kings was King Ashur Nasir Pal II.

\section{HISTORICAL INTRODUCTION: THE DEFINITION OF THE CONCEPT OF MILITARY THOUGHT IN MESOPOTAMIA.}

\section{a- The concept of military thought and its development in Mesopotamia.}

There are many concepts and definitions of military thought, there are those who dealt with his definition in a general theory; he knew it from an ideological point of view, and there are those who linked his definition to the national goals of his country. If the concept of military thought is to be recognized, it is important to know the extent of its connection to military doctrine, military doctrine, or military strategy. 
Military doctrine is related to military thought, by its devotion to it, from (the theoretical side), or to the (Craft) military profession (the material and practical side) (Al-Amamy, 1995, 70). The military doctrine emanating from military thought (Jabr and Aloun, B.T., 1). The drawn military policy that expresses the official views of the state in matters of armed conflict, and includes everything related to the nature and purpose of the war from its point of view - the methods of its administration, and the fundamental foundations for preparing. The country and the armed forces of war, in addition to the set of justifications, humanitarian, religious and moral premises and disciplined intellectual convictions that give legitimacy to the military forces to take action (Al-Shahrani, BT, 10).

From the above, it can be said: Every country, organization, body, or party has its own military doctrine, which is formulated from the general culture of that country or organization. The military doctrine of the state is the product of all scientific and practical research and experience that seeks to crystallize the point of view of that country (or organization, etc) in achieving its security, imposing its sovereignty, upholding its word, and the military doctrine of the state occupies the forefront of its war strategy, because the doctrine determines Ideas.

The broad military outlook from which the war strategy emerges, and the correct answer to a specific one, is the following: (Al-Majdoub, 1974, 45-46):

1. The shape, nature and dimensions of the impending armed conflict, and its desired and hopeful fruits.

2. Method of planning, and method of managing war.

3. Country plans for war.

4. Building and preparing the armed forces to go to war.

5. Providing the theater of war and the means of civil defense from the depth and rear of the state.

6. Preparing the material and technological base, and accumulating the strategic stocks necessary for the imminent war.

7. Ideological and moral preparation for citizens to fight the war and bear its horrors and hardships.
8. Studying the enemy that is planning to fight the impending war against it.

It is clear from what has been mentioned that the military strategy is a product of the military ideas that emerge from the military doctrine, and therefore it can be said: The strategy is linked in terms of its specificity to the military doctrine.

As for the military doctrine: it changes with the change of arms, its extent, the intensity of equipment and formations, the nature of the land, threats and the extent of the ability to perpetuate the combat effort and other things that the military doctrine must work in its various environments, meaning that the military doctrine is required to work in a central region whose ranges lie between a military doctrine Stable that does not accept change between natures and physical environments that are difficult to adapt or respond (Al-Subaie, BT, 1).

On the relationship of the doctrine to the doctrine; the doctrine provides the military doctrine with the legitimacy of the method that will be used in the implementation of operations, leading to the completion of tasks including objectives and results, leaving the war behavior governed between those goals and justifications and those results arising from the war, just as the doctrine determines the legitimate military doctrine and gives it Moral and human characteristic, starting with preparations, building forces and training, and ending with the fighting itself and its consequences (Al-Hayali, 2013, 14).

Based on the foregoing, it can be said that military thought: it is a set of military studies and research, which are prepared by specific people; according to a specific regulator linked to the culture of the environment in which they live, inspired by their ideas from the experiences of others, or their experiences that have not been successful, to put after This is their combat ideas that result in a suitable military strategy, and this does not prevent the existence of common denominators in military ideas between different environments, cultures and civilizations.

Military thought, like other sciences, went through several stages, and thinkers wrote about it 
research and strategies, starting from ancient and middle ages, and ending with the modern era. The thinkers found themselves in front of martial and military events and facts that attracted them to produce their ideas concerning those facts and events, and therefore the phenomenon of fighting was not the result of military axioms written by intellectuals. Since God Almighty created Adam and the idea of killing exists, this is evident in the rise of Cain killing his brother Abel, God said Almighty: \{Cut him, so he killed my brother? He killed him ugliness from the losers\} (Surat al-Ma'idah: V30). The fighting is a desire and instinct within the human being, that meets his need to obtain and defend his intractable right, or an infringement on the right of others, in the hope of his material and moral goods.

Hence the planning, thinking in managing the fighting and how it was done, and the emergence of the plans was associated with the emergence of the fighting itself, without codifying strategies for it in its beginnings, and with the development of events and their greatness, stakeholders began writing down what these ideas revolve through military teachers called them (tactics) (Sami) 10, 2017).

The names given to ancient Iraq were numerous. The Arab historians translated the Greek word (meaning) (Mesopotamia). Despite the accuracy of this translation, it is not (Mesopotamia) comprehensive because the homeland of the Iraqi civilization was not confined to Mesopotamia, but it extended to its surroundings and many archaeological habitats such as slaves, Aridu and Ur erected west of the Euphrates, and they created us (Tel Asmar) and Nuzi east of the Tigris, so they added the word (Mesopotamia) Some Greek writers have recognized themselves to verbal palaces ie, outside and around the two rivers. Abdul-Aziz Saleh sees that we say (Parapotamia) and that the term Mesopotamia and Mesopotamian civilization does not fully mean because the tributaries of the river differ from the river itself (Saleh, 1999, 432-433).

The first topic: King Ashur Nasser Pal II, the definition of his biography and military activities

\section{The first requirement: King Ashur Nasser Pal II, one} of the kings of the Chaldean state in Mesopotamia:

Before entering the identification with the personality of the king (Ashur Nasser Pal II), one of the kings of the Assyrian state of Mesopotamia, we must explain to us the term (Mesopotamia). The names given to ancient Iraq, between Mesopotamia are numerous, but they are not comprehensive because the homeland of the Iraqi civilization was not confined to Mesopotamia but rather extended to and around it and many archaeological habitats such as slaves, Aridu and Ur erected west of the Euphrates, and they waged us ( Tel Asmar) and Nuzi east of the Tigris, and that the term Mesopotamia and Mesopotamia civilization does not fully mean the tributaries of the river differ from the river itself (Mahran, 1990, 5).

Mesopotamia is a Greek word and means between the two rivers, the Tigris and Euphrates rivers, an ancient region located in the eastern Mediterranean Sea bordered by the Zagros Mountains to the northeast and the Arab plateau from the southeast, and today the name of Mesopotamia is called Iraq, and it is worth noting That Iran, Syria, and Turkey are located in the area between the two rivers as well, and this area was called in the name of the Fertile Crescent in the past (Joshua, 2018), where its fertile plains in the past were the site of many civilizations such as the Akkad, Sumer, Babylon, and Assyrian civilizations.

Ashur Nasser Gal II was the king of Assyrian from the period $883 \mathrm{BC}$ to $859 \mathrm{BC}$, and he is also called Ashur Nasser Pal, and his father succeeded Tukulti Ninurta II. Ashur Nasser Pal II subjugated Mesopotamia and also the region that is now Lebanon and added them to the growing Assyrian Empire. He was famous for brutality and enslaved the prisoners to build the new Assyrian capital in Rabwat al-Nimrud Kalh, where he built and built many wonderful monuments.

Ashur Nasser Pal II was a wise administrator and he realized that he could gain greater control and rule over his empire by appointing Assyrian rulers over the countries under his control or relying on a local ruler to pay tribute (Healy, 1991,10). 
Ashur Nasser Pal II inherited from his father, Tawakolti-Nunurta II, a vast, strong and established kingdom. This Assyrian king combined the typical traits of the Assyrian military king, the ruthless conqueror, the organized administrative, and the great construction. His features, expressed in his statues found in "Nimrod" (such as the Old Fale), indicate a strong, resolute and standard figure (Olmstead, 1923,24).

One of the architectural works undertaken by Ashur Nasser Pal II in the early years of his feast was the rebuilding of the ancient city of Kaleh (Nimrod), which was founded by the ancient king, "Chilmansir I" (1245 - 1274 BC). But it was neglected after him did the ruin. Therefore, Ashur Nasser Pal II founed to renew it, rebuild it and take it as a capital, especially its military capital, so that it would include barracks for soldiers and military equipment, and from them the war campaigns were going on. The location of this city, like the ancient capital of Assyrian, was of special strategic importance. The Tigris protects it from its western side, and from its southern side the upper Zab, which connects to the Tigris a short distance south of Nimrod, is in the place called "Mukhallat".

This king has made great efforts in his project so that it is correct to say that he founded the city again. He only changed its ancient ruins on the land and expanded the area of its buildings $\left(3,5 \mathrm{~km}^{2}\right)$. He chose one of the natural heights in one of the corners of this rectangle to act as "the Acropolis", where the location of the city "ziggurat" (the amphitheater), the city's temples and his royal palace. A stream of water from the upper Zab was brought to the city to increase its protection and benefit from it for irrigation also in the adjacent agricultural plain (Sidney, 1928,33).

The second requirement: the definition of the importance of the Phoenician cities and the directions of King Ashur Nasser Pal II, their direction

The Phoenicians are one of the peoples of ancient Phenicia. They are said to be merchants and colonists who came from the Persian Gulf region, in the year $3000 \mathrm{BC}$, to the Levant, North Africa, Anatolia, and Cyprus. The first origins of the Phoenicians were found in the Middle East, where they spoke the Semitic language, and they occupied the Mediterranean coast. Recent exploration excavations that took place in the Phoenician city of Jbeil showed that trade existed between Egypt and Byblos in the year 2800 BC. Important Phoenician remains were found in Jerusalem, Jericho, and Megiddo. By 1250 BC, the Phoenicians were navigators and merchants in the Mediterranean world, and wherever the Phoenicians traveled along the coast, they established colonies for them, which later became independent states (www.encyclopedia .com / phenicia).

Phenicia was unable to remain isolated or neutral in the face of the rivalries that attracted the ancient world and had to brave its fire or take sides with one of them, and its inclusion was a necessity that all major empires were keen to secure due to its great resources, great trade, and great fleet (Mahran, 1994, 130-131).

Reasons for the Assyrian trend towards the Phoenician cities (Philip, 1972, 173):

1. The Assyrian military force has reached a sum of force with which it can implement its policy.

2. The contraction of the Egyptian force (the twentieth family) after its bitter struggle with the peoples of the sea and as a result of its internal problems, and its weak influence in Syria.

3. The subsistence of the sea peoples 'diet of the Hittite caliphs in Asia Minor and the demise of their prestige from the souls of their neighbors.

4. Ashur Nasir Pal II inherited from his father Tawakolti Ninurta II a vast, powerful and steadfast kingdom. This Assyrian king combined the typical characteristics of the Assyrian military king, a brutal conqueror, and the great organized, administrative and constructive king (Taha, 2009, $55)$.

Ashur Nasir Pal II is described as the harshest of the Assyrian kings (DuPont, 2004, 106). However, he elevated the Assyrian Empire almost to the level it reached about two hundred years ago, that is, during the reign of Plassat I. But with his cruelty and hardness he tied the bonds of the empire more than it was at that time (Antoine, 1967, 288). 
Ashur Nasir Pal II started his war operations from the east. Then heading to the northeast of Assyria, then moved his operations to the western borders of Assyrian, colliding with the Aramaic elements and achieving great success in hitting the Arameans congregations in the west, and since then we see that he was going in his wars according to a specific plan (Abdul Qadir, 1987, 59).

When Ashur Nasir Pal II crawled himself at the head of a campaign against the Aramaic kingdoms between the Euphrates and the Tigris, he treated them with the utmost cruelty and brutality. As a result, there was no insurrection or rebellion in this area against the Assyrians (Murkat, 1967, 288).

Among the most important states of the Aramaic cities that were captured by Ashur Nasir Pal, Beit Beyhani and Beit Adeni (Al-Hilu, 2004, 659). He also lists the types of tribute he received and took from these cities (DuPont, 2004, 10).

After the elimination of the Arameans, the road to the west became wide open to the Mediterranean and the Phoenician cities in particular. In any case, Ashur Nasir Pal II continued his march to Lebanon and the cities of the Phoenician coast after receiving the royalty from the kings of the land of Hatti and King Unqi, then the number of cities he passed through until he reached Lebanon (Lukenbill, 1926,275).

In fact, Ashur Nasir Pal II set out from its capital, Kalah (Nimrod), to the Phoenician coast, through the Arameans, to the Phoenician coast, and took the tribute from the kings of the coast and the number of Phoenician cities that paid the tribute, namely, Tire, Sidon, Jbeil, Arwad, his shops, Meza, Kiza, and Amuru (Naguib) (1966, 12).

The Phoenician cities realized that they were too weak to resist and that safety in surrender to the Assyrian king was that they were protected within Lebanon and lived in naturally protected areas without arousing any great power (Karlheinz, 1999, 158).

Accordingly, the Kings of the Phoenician cities, whose main concern was to preserve their trade and profits, were to collect the money and give it as a gift and a reward, as this for material sacrifices protected the cities from destruction during the Assyrian campaigns and the nominal submission and tax policy proved to be effective (Contino, 1997, 271). But paying the Phoenicians tribute does not mean that all of their regions became Assyrian colonies. The aim of the Assyrian campaign was to sow panic among the people and to obtain the largest possible booty (DuPont, 2004, 107). King Ashur Nasser Pal II did not interfere in the affairs of the area south of the line from Nineveh to Tire to seize Damascus until then, as he was soberheaded that he knew where to stop before entering into a conflict with the powerful Damascus (Delaport, 1997, 304).

\section{CONCLUSIONS}

1- The personality of King Ashur Nasser Pal II was unique in that it combined the typical characteristics of the Assyrian military king, the ruthless conqueror, the organized administrator, and the great builder.

2- King Ashur Nasser Pal II became famous for his cruelty and brutality towards his opponents, especially the Aramaic kingdoms between the Euphrates and the Tigris.

3- King Ashur Nasser Pal II restored the prestige of the Ashurian empire by contributing to the bonding of its ties to what it was at that time.

4- King Ashur Nasser Pal II reconstructed the ancient city of Kaleh (Nimrod), after the ruin that had been neglected after the reign of the ancient king "Chilmansir" (1245 - 1274 BC) took place and made it a capital.

5- That the information about the Phoenician cities is limited and mysterious, as it refers to the Cedar Forest and access to the Mediterranean, and only the cities of Jbeil were mentioned by the cities of Jbeil as a source of wood.

6- There are reasons and motives, the most important of which are geographical and economic, in addition to the political situation of the Assyrian at the beginning of the first millennium BC, which pushed them to head west to the Phoenician cities. 
7- The Ashurians confronted in their campaigns to the Phoenician cities the resistance of the Aramaic states, which formed a barrier from reaching the Mediterranean and the Phoenician cities, and when they were eliminated, the road to the west became open.

\section{MARGINS:}

\section{FIRST: ARAB REFERENCES}

1. Ibn Manzur (1999), Tongue of the Arabs, Dar AlAhyaa for Arab Heritage, Beirut, vol. 11, Article (Fikr).

2. Al-Asfahani, Al-Ragheb (1992), Vocabulary of the Words of the Qur'an, with an investigation: Safwan Adnan Daoudi, first edition, Dar Al-Alam in Damascus, and Dar Al-Shamiya, Beirut.

3. Al-Imamy, Salim Shaker (1995), The Arabs and War, Arab Foundation for Studies and Publishing, Beirut.

4. Antoine, Murutkat (1967), Ancient Near Eastern History, Ter: Tawfiq Suleiman, The Establishment Press, Damascus.

5. Anis, Ibrahim and others (1972), The Intermediate Dictionary, Islamic Library Edition Istanbul, Turkey, Second Edition, Part Two, Article (Fikr).

6. Bin Zakaria, Ahmed (1991), Language Standards, Achievement of Abdul Salam Muhammad Haroun, Dar Al-Jeel, Beirut, I 1, Part 4, Article (Fikr).

7. Jabr, Alwan, the strategy between military origin and political necessity and its impact on the balance of international powers.

8. Al-Helou, Abdullah (2004), Ancient Syria, A.B., Al-Adeeb, Damascus, 1st edition.

9. DuPont, Sumer (2004), Arameans, Ter: Father Albert Abona, Baghdad.

10. Delaporte (1997), Mesopotamia (the Babylonian and Assyrian civilizations), see: Muharram Kamal, Egyptian General Book Authority, Cairo.

11. Sami, Alaa (2017), the development of Palestinian military thought between the years (1935-1968), Master Thesis, College of Arts, Islamic University, Gaza.

12. Al-Shahrani, Saad bin Ali, Military doctrine in the Prophet's Wars, College of Da`wa and Fundamentals of Religion, Umm Al-Qura University.
13. Saleh, Abdulaziz (1999), The Ancient Near East "Egypt and Iraq" Part I, The Anglo-Egyptian Library, Cairo.

14. Al-Tabari, Abu Ja`far (1328), Tafsir al-Tabari, AlAmiriya Grand Press, Cairo, c 24.

15. Taha, Baqer (2009), An Introduction to the History of Ancient Civilizations, Dar Al-Warq Publishing Ltd., Beirut, 1st edition.

16. Abdel Qader Khalil Abdel Moneim (1987), The Foreign Policy of King Ashur Nasser Pal II between 880-883, The Egyptian Historical Journal, Volume 34.

17. Abdel-Baqi, Mohamed Fouad (1364), The Indexed Dictionary of Words of the Noble Qur'an, The Egyptian Book House, Cairo, Article (Fikr).

18. Al-Alwani, Taha Jaber (1989), The Intellectual Crisis, The International House of Islamic Book, Riyadh.

19. Philip, until (1972), the history of Lebanon from the earliest times to the present day, see: Enppe Freiha, House of Culture, Beirut, 2nd edition.

20. Karlheinz, Bernhardt (1999), Old Lebanon, Ter: Michel Kilo, Qudamus Publishing and Distribution, Damascus, p. 1.

21. Contino (1997), The Phoenician Civilization, The Egyptian General Book Organization, Cairo.

22. Mahmoud, Ahmad (2011), The Military Dictionary, Lebanon Publishers Library, Beirut.

23. Mahran, Mohamed Bayoumi (1994), Phoenician cities, Arab Renaissance House, Cairo.

\section{SECOND: FOREIGN REFERENCES}

1- Healy, Mark (1991). The Ancient Assyrians. New York: Osprey.

2- Joshua J. Mark (14-3-2018), "Mesopotamia" www.ancient.eu

3- Lukenbill,D.D.(1926), Ancient Records of Assyria and Babylonia ,vol.I ,Chicago.

4- Sidney, Smith (1928). Early history of Assyria. U.K: Chatto \& Windus.

a- T Olmstead (1923). History of Assyria. New York: C. Scriber's sons; 1st Edition.

\section{THIRD: ELECTRONIC WEBSITES}

1- www.encyclopedia.com/phoenicia 